\title{
Kombucha Fermentation from Cascara with Addition of Red Dragon Fruit (Hylocereus polyrhizus): Analysis of Alcohol Content and Total Soluble Solid
}

\author{
M Muzaifa, $^{2, *}$, S Rohaya ${ }^{1,2}$, C Nilda ${ }^{1,2}$, and K R Harahap ${ }^{1}$ \\ ${ }^{1}$ Post Harvest Technology Department, Universitas Syiah Kuala, Jalan Tgk. Hasan Krueng Kalee 3, Darussalam- \\ Banda Aceh 23111, Indonesia \\ ${ }^{2}$ Riset Pusat Halal Universitas Syiah Kuala \\ *Corresponding author. Email: murnamuzaifa@unsyiah.ac.id
}

\begin{abstract}
Dried coffee skin (cascara) can be used as a raw material for making kombucha because it still contains a number of important nutrients. The addition of fruit to kombucha fermentation is currently widely used to get the sensation of carbonated drinks but has the potential to increase the alcohol content. In connection with the Indonesian Ulema Council (MUI) fatwa regarding the halalness of food/beverarge containing alcohol, the alcohol content in kombucha fermentation with the addition of fruit needs special attention. This study aims to examine the alcohol content and total soluble solid of kombucha made from casacara with the addition of dragon fruit with different fermentation times. This study used a factorial randomized block design consisting of 2 (two) factors, the fruit treatment used (P), consisting of 2 levels, $\mathrm{P} 1$ = fruit slices and $\mathrm{P} 2$ = fruit juice. The second factor is the second fermentation time (L), consisting of 4 levels, namely: $\mathrm{L} 1=2$ days, $\mathrm{L} 2=4$ days, $\mathrm{L} 3=6$ days and L4 $=8$ days. The results showed that fruit treatment $(\mathrm{P})$ had a very significant effect on the ethanol content of kombucha cascara. The length of fermentation has a very significant effect on the ethanol content and total soluble solids of kombucha cascara. The interaction of the two treatments had a very significant effect on the alcohol content of kombucha cascara. The alcohol content of kombucha cascara with the addition of dragon fruit ranged from $0.60-1.31 \%$ with an average of $0.84 \%$ and the total soluble solids ranged from 9.87- $11^{\circ}$ Brix with an average of $10.42^{\circ}$ Brix. The alcohol content of kombucha cascara is still higher than the minimum alcohol content stipulated by MUI Fatwa No. 10 of 2018. Further research is needed to reduce the alcohol content of kombucha with fruit added in the second fermentation.
\end{abstract}

Keywords: Kombucha fermentation, Cascara, red dragon fruit, alcohol content, total soluble

\section{INTRODUCTION}

Coffee is one of the leading commodities in the plantation sub-sector that significantly contributes to generating foreign exchange for Indonesia. Data from the Ministry of Industry of the Republic of Indonesia [1] shows that there was an increase in the country's foreign exchange by $10 \%$ compared to the previous year from the export value of the coffee processing industry of 639,000 tons. Aceh province, precisely in the Gayo highlands, is one of the largest coffee producers in Indonesia. Aceh produces 61,761 tons/year of Arabica coffee with an average productivity of 773 tons/hectare [2].
The increase in coffee production is also accompanied by problems that exist in coffee processing, especially the generated waste. Coffee processing produces a number of wastes, such as pulp, husk and silver skin, which so far have not been used optimally. One of the economical uses of coffee skin is to process it into cascara $[3,4]$. This cascara can be obtained from several types of coffee treatments with different qualities [5]. Furthermore, Muzaifa et al [6] has studied the manufacture of cascara as a raw material for kombucha. The diversification of processed products based on coffee by-products is expected to be able to optimize their utilization and actually be able to overcome the problem of coffee waste. 
The next innovation that can be done to improve the nutrition and taste of kombucha cascara with the addition of fruit. Currently, kombucha is starting to develop with the addition of fruit variants so that it enhance a fizzy sensation with more attractive colors and aromas. The addition of this fruit can be done in the form of pieces or fruit [7]. The addition of fruit in kombucha processing is usually done after the kombucha has been fermented, which is about 8-12 days. After 8-12 day, the fruit was added and fermented again for a few days (continuation/second fermentation). The amount of fresh fruit or dried fruit added in the second fermentation is about $10-15 \%[8,9]$.

One fruit that is high in nutrients and has an attractive color is the red dragon fruit (Hylocereus polyrhizus). This fruit is has a sweet sour taste with an attractive purplish red color $[10,11]$. In addition, red dragon fruit is also a tropical fruit that has not been used optimally and is generally only consumed directly.

The process of kombucha processing which involves fermentation is may contain a small amount of alcohol in the final product. The addition of fruit in further fermentation has the potential to increase the alcohol content of kombucha. The yeast in active kombucha converts the sugar in the fruit into alcohol and $\mathrm{CO}_{2}$ which produces carbonated kombucha [7]. The increase in alcohol needs to be a concern because the Indonesian Ulema Council (MUI) Fatwa No. 10 of 2018 states that drinks containing $0.5 \%$ ethanol are categorized as khamr, intoxicating alcoholic beverage. On the other hand, kombucha drinks throughout the history of their existence are not categorized as intoxicating beverages. Kombucha are well-known as a functional beverage that has many health benefits $[12,13]$. After all, caution is needed for a Muslim in responding to the MUI fatwa. One of them is knowing the alcohol content of kombucha which is added by fruit in its production. Therefore, this study aimed to examine the ethanol content of kombucha coffee skin with the addition of dragon fruit at different fermentation times.

\section{MATERIALS AND METHODS}

\subsection{Materials}

The main raw material used in this research was cascara, which was obtained from the by-product of honey coffee processing in Takengon, Aceh Tengah Regency. Other additional ingredients were red dragon fruit, sugar, water, kombucha culture (SCOBY) that contains yeast and bacteria, aquades and absolute ethanol.

\subsection{Research Design}

This study used a factorial randomized block design (RBD) consisting of 2 (two) factors. The first factor is the treatment of the fruit (B), consisting of 2 levels, namely $\mathrm{B} 1=$ fruit pieces, $\mathrm{B} 2=$ fruit juice. The second factor is the second fermentation time (L), which consists of 4 levels, namely: $\mathrm{L} 1=2$ days, $\mathrm{L} 2=4$ days, $\mathrm{L} 3=6$ days and L4 $=8$ days. Each treatment was repeated 3 times so that a total of 24 experimental units were obtained.

\subsection{Research Procedure}

\subsubsection{Cascara tea processing}

Cascara tea is made by brewing cascara (husk cascara) which is obtained from the processing of "honey process" coffee. Cascara tea processing refers to the research conducted by Putri [14] with slight modifications. Cascara as much as $270 \mathrm{~g}$ is brewed for 8 minutes with $9600 \mathrm{ml}$ of boiling water. Cascara is filtered and added sugar as much as $20 \%$ in hot condition, stirred until smooth and cooled to room temperature.

\subsubsection{Kombucha cascara processing}

The procedure for kombucha cascara processing refers to the research by Putri [14] and Naland [15].

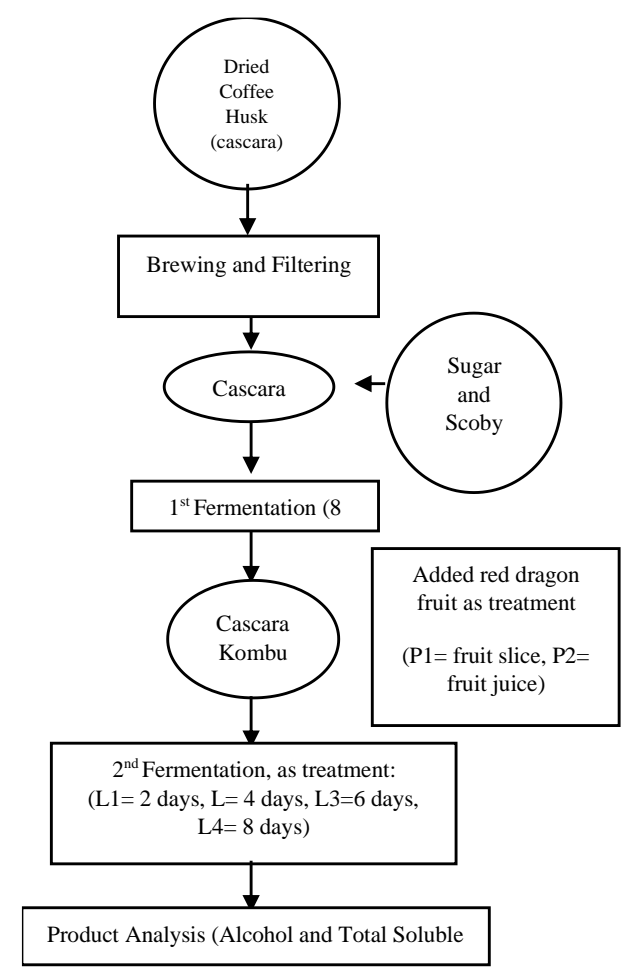

Figure 1. Research Flow Chart

Cascara tea was poured into a $10 \mathrm{~L}$ glass jar, then inoculated with $10 \%$ kombucha or SCOBY starter. The jar was covered with sterile gauze and fermented for 10 days (fermentation 1). The kombucha cascara obtained was then taken $400 \mathrm{ml}$ each and put into a $750 \mathrm{ml}$ glass bottle that had been coded. Furthermore, 10\% dragon 
fruit $(1 \mathrm{~cm} \times 1 \mathrm{~cm})$ was added into each bottle according to the treatment (fruit pieces or juice), tightly closed and further fermented (second fermentation) according to the treatment $(2,4,6$ and 8 days).

\subsubsection{Alcohol content and total soluble solid analysis}

The analysis that carried out on the kombucha cascara product included analysis of the ethanol content and total soluble solids. The ethanol content was analyzed by the dichromate method by Rizqiyah [16] and the total soluble solids were analyzed using a refractometer. The research flow chart can be seen in Figure 1.

\subsection{DATA ANALYSIS}

Data analysis was performed statistically using ANOVA (Analysis of variance). The treatments which showed an effect on the parameters tested were further tested with the Duncan Multiple Range Test (DMRT) $\alpha=0,05$

\section{RESULT AND DISCUSSION}

\subsection{Alcohol content}

The alcohol content in this study ranged from 0.60 $1.31 \%$ with an average of $0.84 \%$. The results of the variance showed that the fruit treatment $(\mathrm{P})$, the second fermentation time (L) and the interaction between treatments $(\mathrm{PL})$ had a very significant effect $(\mathrm{P}<0.01)$ on the ethanol content of red dragon fruit kombucha cascara. DMRT test results indicate kombucha processing with the addition of fruit juice and 8 days of fermentation (P2L4) treatment resulted the highest alcohol content reaching $1.31 \%$ which was different from other treatments as shown in Figure 2.

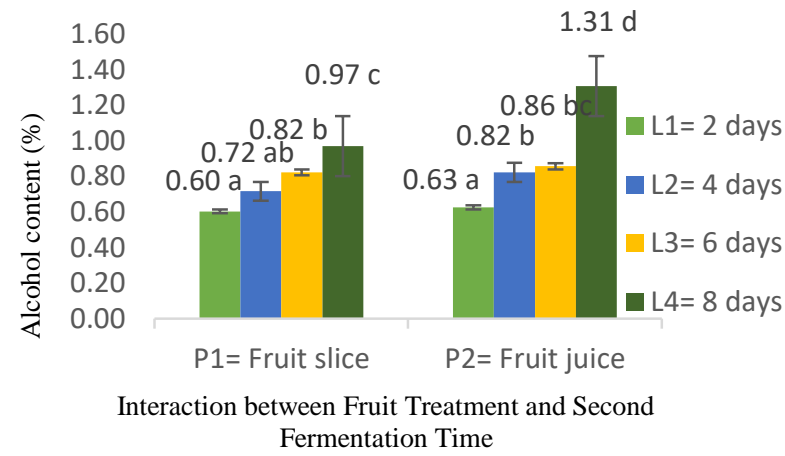

Figure 2. The interaction effect of fruit treatment and second fermentation time on the alcohol content

Figure 2 indicates an increase in alcohol content as the second fermentation time increases, both using fruit pieces (P1) and fruit juice (P2). The length of fermentation is one of the factors that affect the production of alcohol. Alcohol in kombucha fermentation is produced from the breakdown of sugar by yeast, which is one of the microorganisms found in kombucha starter besides acetic acid bacteria [17]. In this research, the addition of red dragon fruit in the second fermentation provided adequate sugar that could be broken down by the yeast present in kombucha. The longer the fermentation resulted the greater opportunity for the yeast to break down the existing sugars so that the alcohol produced increases. Setyohadi et al [18] in Suwarrizki et al [19] is also has the same result that the longer the fermentation, the more sugar will be converted into alcohol so that the higher the alcohol content produced.

At a certain point, alcohol levels are expected to decrease, but in this study which was limited to only 8 days, the decreasing could not be observed. Pratiwi et al [20] have observed an increase in kombucha alcohol from day 4 to 12 and then decrease on day 12 . The decrease occurred when acetic acid bacteria used the alcohol formed to form acetic acid and this reaction continued until sugar in the solution turns into organic acids which causes a decrease in alcohol content.

In term of the fruit use, the alcohol content of kombucha cascara with added fruit juice tends to be higher than that of dragon fruit pieces. The higher alcohol content indicates the more efficient use of substrate [21]. This result shows that the sugar in fruit juice is processed (fermented) faster by microorganisms than pieces of fruit because it has a larger surface area. The larger the surface area of the reactants, the greater their ability to react so that the reaction rate will also be faster until the substrate is used up and reaches optimum fermentation. Thus the resulting alcohol will be higher [22].

In the history of its use, kombucha is known as one of the health drinks. Kombucha is also known still contain alcohol in small amounts, which is around $0.17 \%-0.55 \%$ [23]. However, Spedding [24] stated the average range of alcohol content in kombucha was $0.75-1.25 \%$, similar to the results of a Food and Drug Administration (FDA) investigation of $0.7-1.3 \%$ [25]. There have been no reports of kombucha being an intoxicating drink. However, with the MUI fatwa No. 10 of 2018 which stipulates a minimum limit of $0.5 \%$ alcohol for beverages which is taken into consideration in consuming and producing kombucha in Indonesia. Further research is needed to determine the best fermentation conditions (fermentation time, amount of substrate, sugar content, etc.) to produce kombucha with an alcohol content below $0.5 \%$.

\subsection{Total soluble solid}

The total soluble solids in this study ranged from 9.87 to $11^{\circ}$ Brix with an average of $10.42^{\circ}$ Brix. The results of the variance showed that the second fermentation time 
(L) had a very significant effect $(\mathrm{P}<0.01)$ on the total soluble solids of red dragon fruit kombucha cascara Fizzy. The effect of the second fermentation time on the total soluble solids of red dragon fruit kombucha cascara can be seen in Figure 3.

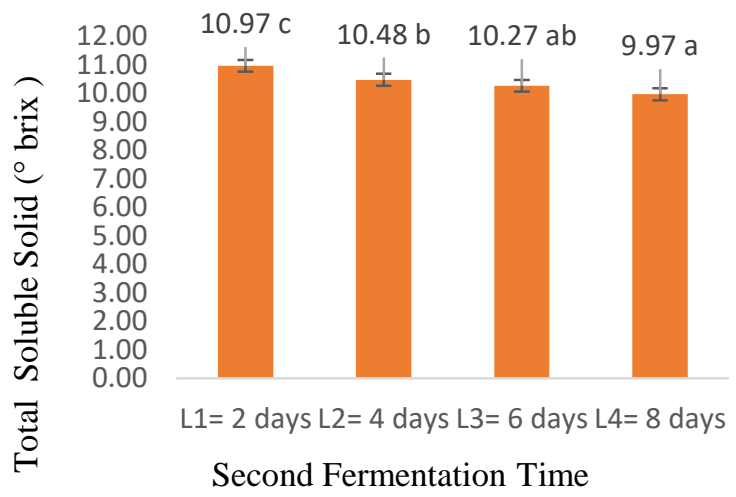

Figure 3. The effect of the second fermentation time on the total soluble solid (Values followed by different letters show significant differences in the $\mathrm{DMRT}_{0,05}$ test)

Figure 3 displays that the total soluble solids tend to decline with increasing fermentation time. The highest total soluble solids was obtained in the second fermentation period of 2 days $\left(10.97^{\circ}\right.$ Brix $)$ which was different from other treatments. Total soluble solid can be used to interpret the amount of sugar contained in foodstuffs. The decreased sugar content in the solution is a sign that microorganisms are active [26].

The pattern of decreasing total soluble solids in the second fermentation time is in accordance with the results of Putra et al. [27], which the highest total soluble solids obtained in kombucha pedada (Sonneratia caesolaris $\mathrm{L}$ ) leaf tea with a fermentation time of 6 days $\left(10,75^{\circ}\right.$ Brix $)$ and at 14 days of fermentation time it decreases to $6.53{ }^{\circ}$ Brix. This result show that the longer the fermentation, the total soluble solids of kombucha produced become lower due to substrate degradation, such as sugar and other solutes in kombucha as a form of activity and growth of microorganisms. According to Dufresne and Farnworth [28], there are two groups of microorganisms found in starter kombucha, specifically acetic acid bacteria and yeast. Acetic acid bacteria found included Acetobacter xylinum, A. xylinoides, Bacterium gluconicum, A. aceti, A. pasteurianus. Meanwhile, the yeasts found were Schizosaccharomyces pombe, Saccharomycodes ludwigii, Kloeckera apiculata, Saccharomyces cerevisiae, Zygosaccharomyces bailii, Brettanomyces bruxellensis, B. lambicus, B. custersii, Candida and Pichia.

The fermentation process begins with the breakdown of sugar by yeast into alcohol, while acetic acid bacteria use glucose, glucuronic acid and alcohol to produce acetic acid [29]. Thus it is clear that the longer the fermentation of the main substrate which is sugar will decrease. This result also occurs in the kombucha fermentation of apples, which increases in sugar content with the longer fermentation time [30].

\section{CONCLUSION}

Kombucha cascara processing with the addition of red fruit in the second fermentation affects the alcohol content and the total soluble solid. The longer the second fermentation, the higher the alcohol content, on the contrary, the total soluble solid decreased. The alcohol content of kombucha cascara with the addition of dragon fruit ranges from $0.60-1.31 \%$ with an average of $0.84 \%$, higher than the minimum alcohol limit set by MUI Fatwa No. 10 of 2018. Thus, a longer second fermentation time is required to lowering the alcohol content of kombucha with added fruit.

\section{REFERENCES}

[1] Kementerian Perindustrian Republik Indonesia 2018 Press Release

[2] Sekretariat Daerah Aceh 2019 Aceh Government Report

[3] Muzaifa M, Hasni D, Arpi N, Sulaiman M I and Limbong M S 2019 JTPA 23 136-42

[4] Muzaifa M, Andini R, Sulaiman M I, Abubakar Y, Rahmi F and Nurzainura 2021 IOP Conf. Ser.: Earth Environ. Sci. 644 1-8

[5] Arpi N, Muzaifa M, Sulaiman M I, Andiri R and Kesume S I 2021 IOP Conf. Ser.: Earth Environ. Sci. 709 1-9

[6] Muzaifa M, Rahmi F and Syarifudin 2021 IOP Conf. Ser.: Earth Environ. Sci. 672 1-9

[7] Evans F 2018 Fermented Probiotic Drinks At Home (New York: The Experiment)

[8] Deanna 2019 Homestead and Chill

[9] Fermentaholics 2019 Kombucha Secondary Fermentation

[10] Marlina M, Wijaya M and Kadirman K 2019 JPTP $585-97$

[11] Putri D C L A, Putra I N K and Suparthana I P 2019 Itepa 8 8-17

[12] Mousavi S M, Hashemi S A, Zarei M, Gholami A, Lai C W, Chiang W H, Omidifar N, Bahrani S and Mazraedoost S 2020 Hindawi 2020 1-14

[13] Chakravorty S, Bhattacharya S, Bhattacharya D, Sarkar S and Gachhui R 2019 Elsevier 285-327

[14] Putri K O 2020 Thesis Teknologi Hasil Pertanian Universitas Syiah Kuala 
[15] Naland H 2004 Kombucha: Teh Ajaib Pencegah Aneka Penyakit (Jakarta: Agromedia Pustaka)

[16] Rizqiyah R 2007 Thesis Pendidikan Kimia UIN Sunan Kalijaga

[17] Villarreal-Soto S A, Beaufort S and Bouajila J 2018 J. Food Sci. 83 580-88

[18] Setyohadi 2006 Proses Mikrobiologi Pangan (Proses Kerusakan dan Pengolahan) (Medan: USUPress)

[19] Suwarrizki G P G B, Gunam I B W and Wijaya I M M 2019 JITP Agrotechno 4 44-53

[20] Pratiwi A, Elfita and Aryawati R 2021 Mar. Sci. Res. 4 131-36

[21] Hawusiwa E S, Wardani A K and Ningtyas D W 2015 JPA UB 3 147-55

[22] Suherti E 2016 Teaching Resource Direktorat Jenderal Guru Dan Tenaga Kependidikan Kementerian Pendidikan dan Kebudayaan

[23] Kallel L, Desseaux V, Hamdi M, Stocker P and Ajandouz E H 2012 Food Res. Int. 49 226-32

[24] Spedding G 2015 A Review

[25] Kapp J M and Sumner W 2019 Ann Epidemiol 30 66-70

[26] Ginting S O, Bintoro V P and Rizqiati H 2019 JTP 3 104-09

[27] Putra A, Muhaimin and Wulansari D 2021 UNJA 1 1-8

[28] Dufresne C and Farnworth E 2000 Food Res Int 33 409-21

[29] Jayabalan R, Malbaša R V, Lončar E S, Vitas J S and Sathishkumar M 2014 Compr. Rev. Food Sci. F 13 538-50

[30] Zubaidah E, Ifadah R A and Afgani C A 2019 IOP Conf. Ser.: Earth Environ. Sci. 230 1-6 